\title{
A Pin -Offering
}

\section{G. Montagu Benton}

To cite this article: G. Montagu Benton (1908) A Pin -Offering, Folklore, 19:1, 92-92, DOI: 10.1080/0015587X.1908.9719815

To link to this article: http://dx.doi.org/10.1080/0015587X.1908.9719815

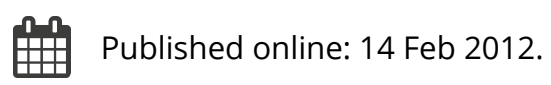

$$
\text { 世 Published onlie: } 14 \text { Feb } 2012 .
$$

Submit your article to this journal 6

Џll Article views: 1

Q View related articles $\sqsubset$ 


\section{A Pin-Offering.}

The following excerpt from the Church Times of Sep. 1 3th, 1907, is, I think, worth recording. The writer after giving some description of the Norman building called St. Aldhelm's Chapel, Worth, Isle of Purbeck, goes on to say: "Mr. Moule tells us that, during the time of its dilapidation, it was the custom of the parishioners of Worth, on Thursday in Whitweek, to visit this building, deck it with flowers, and dance therein; it used at that time to pass by the name of the Devil's Chapel. There was an old custom, still maintained, of placing a pin in an opening of the central shaft, accompanying the action with a silently expressed wish. When visiting the building on two occasions last August, about a dozen pins were noticed in the aperture, which is not to be wondered at, since all the cheap guide-books exploit its fame in this direction. On my last visit a young lady, apparently of some refinement and education, entered the fabric, at once proceeded to the pin-hole, and deposited her contribution, at the same moment closing her eyes with a rapt expression of countenance, whilst her lips moved as she mutely made her wish."

\section{G. Montagu Benton.}

Cambridge University Museum.

\section{Notes on Some Customs of the Bangala Tribe, UPPER CONGo.}

I. DURINg the first few hours after the death of a woman nearly all her female neighbours cry as though their hearts were broken, but the next day they commence dancing, and continue to do so at short intervals, for five or six days. The husband hires a professional dancer to act as master of the ceremonies.

II. In the farm of the dead woman a ring is made by throwing up a bank of earth, and in this ring are placed the saucepans, hoes, mats, and private property of the deceased, together with. 